\title{
Effect of calcium applications on ion accumulation in different organs of pepper plant under salt stress
}

\author{
$F$. Yasar ${ }^{*}$ and $O$. Uzal \\ Van Yuzuncu Y1l University, Van, Turkey
}

\begin{abstract}
The present study was carried out in a climate chamber and water culture of physiology laboratory of Van Yüzüncü Y1l University, Faculty of Agriculture, Department of Horticulture. Demre pepper varieties are used in the study of different levels of calcium (Ca) morphological and biochemical effects of pepper plants under salt stress were investigated. The study was carried out in 16/8 hour light / dark photoperiod, $25{ }^{\circ} \mathrm{C}$ and $\% 70$ humid climate chamber in controlled conditions. In order to determine the biochemical changes occurring in stressed plants, the amount of ions $\mathrm{Na}, \mathrm{K}, \mathrm{Ca}, \mathrm{Cl}$ in root, stem and leaves of plants and $\mathrm{Ca} / \mathrm{Na}$ ratio were determined. The accumulation of $\mathrm{Na}$ and $\mathrm{Cl}$ ions was found to decrease in root, stem and leaves as the dose of $\mathrm{Ca}$ increased. It can be said that increasing doses of $\mathrm{Ca}$ applications under salt stress are partially effective in reducing the negative effects of salt.
\end{abstract}

\section{Introduction}

$\mathrm{NaCl}$ reduces water potential and also adversely affects plant growth by disrupting the ion balance in the cell. High $\mathrm{NaCl}$ intake leads to an increase in the accumulation of $\mathrm{Na}+$ and $\mathrm{Cl}-$ ions in the cell and a decrease in $\mathrm{Ca}+2, \mathrm{~K}+$ and $\mathrm{Mg}+2$ concentrations [1]. $\mathrm{Na}+$ entering the plant cell disrupts membrane potential and facilitates passive entry of extracellular $\mathrm{Cl}$ into the cell via anion channels [2, 3]. High salt concentrations decrease the calcium uptake and transport of the plant and cause calcium deficiency and ion imbalance in the plant [4, 5]. In plants under salt stress, it has been reported that potassium is a cofactor for many enzymes and may reduce the harmful effect of $\mathrm{NaCl}$ by external application of $\mathrm{Ca}[6]$.

Calcium is an element that has a positive effect on salt stress. High doses of exogenous calcium reduce the permeability of the cell membrane to $\mathrm{Na}+$ ion. In this way, the accumulation of sodium in the cell and plant is prevented by passive uptake $[7,8]$. The common ideas of researchers trying to explain the role of calcium in the protection of salt stress through various mechanisms; calcium to strengthen the cell membrane and ion selectivity in the uptake and transport. $\mathrm{Ca} 2+$ ion, crosslinking the cell membrane with negatively charged basic groups and thus preserving the structural integrity of the cell membrane is also made in the description $[4,9]$. Rengel [10] (1992) suggested that the calcium element binds to the cell membrane to control the permeability and prevents the release of calcium present in the cell.

In this study, different doses of Ca were applied to pepper plant exposed to salt stress and effects of applications on ion intake were determined.

\section{Materials and methods}

Demre sharp pepper variety was used in the study. The experiment was carried out in a split air-conditioned climate chamber with a humidity of $70 \%$ and a temperature of $25 \pm 2{ }^{\circ} \mathrm{C}$ in a normal atmosphere and in a water culture. In the study, first of all, pepper seeds were sown in $150 \times 25 \times 5 \mathrm{~cm}$ plastic seedlings ( 9 holes with a diameter of $0.5 \mathrm{~cm}$ ) filled with pumice sieved, and watered with fountain water.

For the better development of the seedlings, the cotyledon leaves coming horizontally and the first true leaves began to be seen, irrigation was started with Hoagland nutrient solution [11]. Seedlings, which also formed the $2^{\text {nd }}$ true leaves in the pumice environment, were taken to water culture in $25 \times 25 \times 18 \mathrm{~cm}$ size plastic cuvettes filled with Hoagland nutrient solution. Specially prepared and perforated for each seedling in plastic trays pepper seedlings were placed by wrapping with small sponge pieces. The trays were placed on the trays with the plant roots in the nutrient solution. The aeration was done by immersing the thin plastic hoses connected to the aquarium pump into the nutrient solution.

Seedlings were grown in water culture for two weeks and salt application was started on seedlings having 4-5 real leaves. The experiment was designed according to the exact chance design with three replications and 15 replicates per repetition.

$\mathrm{NaCl}$ was added to the nutrient solution (1/2 Hoagland) with a salt concentration of $75 \mathrm{mM}$. During the regeneration of the repeating solutions every week, the same concentration of salt applications was maintained. Pepper seedlings with salt $(\mathrm{NaCl}) 5$ different doses (150, 200, 250, 300, 350 ppm) Ca was added. As a result, 6 different applications were performed as

Corresponding author: fyasar@yyu.edu.tr 
control, salt + Ca (150 ppm, 200 ppm, 250 ppm, $300 \mathrm{ppm}, 350 \mathrm{ppm})$. The nutrient solution used was prepared according to [11]. The ppm values of all nutrients are given in Table 1.

Table 1. Contents of the nutrient solution used (ppm).

\begin{tabular}{|c|c|c|c|c|c|c|}
\hline Elements & 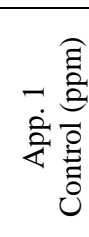 & 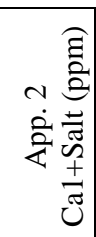 & 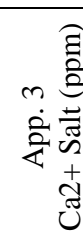 & 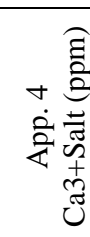 & 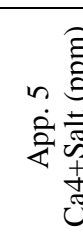 & 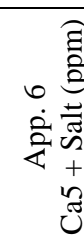 \\
\hline Nitrogen $(\mathrm{N})$ & 186 & 186 & 186 & 186 & 186 & 186 \\
\hline Phosphorus (P) & 31 & 31 & 31 & 31 & 31 & 31 \\
\hline Potassium (K) & 167 & 167 & 167 & 167 & 167 & 167 \\
\hline Magnesium $(\mathrm{Mg})$ & 49,28 & 49,28 & 49,28 & 49,28 & 49,28 & 49,28 \\
\hline Calcium (Ca) & 200 & 150 & 200 & 250 & 300 & 350 \\
\hline Sulfur (S) & 66 & 66 & 66 & 66 & 66 & 66 \\
\hline Iron $(\mathrm{Fe})$ & 3.3 & 3.3 & 3.3 & 3.3 & 3.3 & 3.3 \\
\hline Manganese (Mn) & 0.031 & 0.031 & 0.031 & 0.031 & 0.031 & 0.031 \\
\hline Boron (B) & 0.205 & 0.205 & 0.205 & 0.205 & 0.205 & 0.205 \\
\hline Copper $(\mathrm{Cu})$ & 0.015 & 0.015 & 0.015 & 0.015 & 0.015 & 0.015 \\
\hline Zinc $(\mathrm{Zn})$ & 0.023 & 0.023 & 0.023 & 0.023 & 0.023 & 0.023 \\
\hline
\end{tabular}

Sampling for analyzes was performed on the 20th day of salt application. $\mathrm{Na}^{+}, \mathrm{K}^{+}, \mathrm{Ca}^{+2}$, and $\mathrm{Cl}^{-}$contents were determined in these samples.

\section{Mineral element analysis}

For the ion concentration determinations, fresh root, stem, and leaf samples were extracted in $0.1 \mathrm{~N}$ of nitric acid. The sodium, potassium (K+) and calcium $(\mathrm{Ca}+2)$ concentrations were measured by atomic absorption spectrometry [12], $\mathrm{Cl}$ ion was measured by an automatic chloridometer (Buchler - Cotlove chloridometer) which was analyzed by colorimetric amperometric titration with silver ions. Ion amounts in the fresh plant samples were determined as fresh weight ( $\mathrm{g} / \mathrm{mg}$ Fresh Weight) [13].

In order to evaluate the data obtained as a result of the study, Statgraphics was subjected to variance analysis in statistical analysis package program. Duncan multiple comparison test $(\mathrm{P}<0.05)$.

\section{Results}

At the end of 20 days of $75 \mathrm{mM} \mathrm{NaCl}$ stress application, it was observed that there were differences between the plant organs (root, stem and leaf) in terms of $\mathrm{Na}+, \mathrm{K}$, $\mathrm{Ca}, \mathrm{Ca} / \mathrm{Na}$ and $\mathrm{Cl}$ accumulation (Tables 2-5 and 6).

When the $\mathrm{Na}$ ion in the root was examined, the lowest value in terms of $\mathrm{Na}$ ion was obtained from $\mathrm{Ca} 5+$ Salt (2.474) application compared to the control group (1.125), while the highest value was observed in $\mathrm{Ca} 3+$ Salt $(3,369)$ application. When the $\mathrm{Na}$ ion in the stem was examined, the lowest value in terms of $\mathrm{Na}$ ion was obtained from $\mathrm{Ca} 2+$ Salt (2.105) application compared to the control group (1.226), while the highest value was observed in Ca1 + Salt (7.169) application. When the Na ion in the leaf was examined, the lowest value in terms of $\mathrm{Na}$ ion was obtained from $\mathrm{Ca} 3+$ Salt (2.697) application compared to the control group (0.764), while the highest value was measured in Ca1 + Salt (4.839) application. Na deposition in the roots, stem and leaves of all applications increased compared to the control group. In general, the amount of $\mathrm{Na}$ ion was found to accumulate more in the stem.

Table 2. Na ion accumulations determined in plant organs ( $\mu \mathrm{g} / \mathrm{mg}$ T.A.)

\begin{tabular}{|c|c|c|c|c|}
\hline Application & Root Na & Stem Na & Leaf Na & P Value \\
\hline Control & $1.125 \mathrm{C} \mathrm{a}$ & $1.226 \mathrm{E} \mathrm{a}$ & $0.764 \mathrm{~B} \mathrm{a}$ & $0.1170^{*}$ \\
\hline $\mathrm{Ca} 1+\mathrm{NaCl}$ & $2.886 \mathrm{AB} \mathrm{b}$ & $7.169 \mathrm{~A} \mathrm{a}$ & $4.839 \mathrm{~A} \mathrm{ab}$ & $0.0381^{*}$ \\
\hline $\mathrm{Ca} 2+\mathrm{NaCl}$ & $2.786 \mathrm{AB} \mathrm{a}$ & $2.105 \mathrm{DE} \mathrm{a}$ & $4.113 \mathrm{~A} \mathrm{a}$ & $0.1546^{*}$ \\
\hline $\mathrm{Ca} 3+\mathrm{NaCl}$ & $3.369 \mathrm{~A} \mathrm{a}$ & $3.448 \mathrm{CD} \mathrm{a}$ & $2.697 \mathrm{AB} \mathrm{a}$ & $0.3875^{*}$ \\
\hline $\mathrm{Ca} 4+\mathrm{NaCl}$ & $3.074 \mathrm{AB} \mathrm{b}$ & $5.516 \mathrm{~B} \mathrm{ab}$ & $4.429 \mathrm{~A} \mathrm{~b}$ & $0.0226^{*}$ \\
\hline $\mathrm{Ca} 5+\mathrm{NaCl}$ & $2.474 \mathrm{~B} \mathrm{~b}$ & $3.698 \mathrm{C} \mathrm{a}$ & $2.963 \mathrm{AB} \mathrm{ab}$ & $0.0668^{*}$ \\
\hline $\mathrm{P}$ Value & $0.0005^{*}$ & $0.0000^{*}$ & $0.0175^{*}$ & \\
\hline
\end{tabular}

Differences between means with the same superscript capital letter in the same column are not significant at $\mathrm{P} \leq 0.05$. Differences between means with the same superscript small letter in the same row are not significant at $\mathrm{P} \leq 0.05$.

Table 3. $\mathrm{K}$ ion accumulations determined in plant organs ( $\mu \mathrm{g} / \mathrm{mg}$ T.A.)

\begin{tabular}{|c|c|c|c|c|}
\hline Application & Root K & Stem K & Leaf K & P Value \\
\hline Control & $5.493 \mathrm{~A} \mathrm{a}$ & $10.457 \mathrm{~A} \mathrm{~b}$ & $9.388 \mathrm{AB} \mathrm{b}$ & $0.0010^{*}$ \\
\hline $\mathrm{Ca} 1+\mathrm{NaCl}$ & $2.374 \mathrm{C} \mathrm{a}$ & $3.157 \mathrm{D} \mathrm{b}$ & $7.423 \mathrm{~B} \mathrm{~b}$ & $0.0009^{*}$ \\
\hline $\mathrm{Ca} 2+\mathrm{NaCl}$ & $2.996 \mathrm{BC} \mathrm{b}$ & $4.721 \mathrm{CD} \mathrm{b}$ & $9.905 \mathrm{AB} \mathrm{a}$ & $0.0207^{*}$ \\
\hline $\mathrm{Ca} 3+\mathrm{NaCl}$ & $3.884 \mathrm{~B} \mathrm{~b}$ & $6.734 \mathrm{BC}$ b & $12.505 \mathrm{~A} \mathrm{a}$ & $0.0048^{*}$ \\
\hline $\mathrm{Ca} 4+\mathrm{NaCl}$ & $3.617 \mathrm{~B} \mathrm{c}$ & $7.132 \mathrm{~B} \mathrm{~b}$ & $9.781 \mathrm{AB} \mathrm{a}$ & $0.0010^{*}$ \\
\hline $\mathrm{Ca} 5+\mathrm{NaCl}$ & $3.514 \mathrm{BC} \mathrm{c}$ & $5.069 \mathrm{CD}$ b & $7.124 \mathrm{~B} \mathrm{a}$ & $0.0027^{*}$ \\
\hline $\mathrm{P}$ Value & $0.0019^{*}$ & $0.0001^{*}$ & $0.0724^{*}$ & \\
\hline
\end{tabular}

Differences between means with the same superscript capital letter in the same column are not significant at $\mathrm{P} \leq 0.05$. Differences between means with the same superscript small letter in the same row are not significant at $\mathrm{P} \leq 0.05$.

When the $\mathrm{K}$ ions in the root were examined, the lowest value in terms of $\mathrm{K}$ ions was observed in Ca1 Salt $(2,374)$ application and the highest value was observed in Ca 3 Salt $(3,884)$ application compared to the control $(5,493)$ group. When looking at the amount of $\mathrm{K}$ in the stem (10.457) compared to the highest value of $\mathrm{Ca} 4$ Salt (7.132) application, the lowest value was seen in $\mathrm{Ca} 1$ Salt (3.157) application. When the K ion in the leaf was examined, the lowest amount of $\mathrm{K}$ ion was observed from Ca 5 Salt (7.124) application and the highest value was observed in Ca 3 Salt (12.505) application. Among the organs, $\mathrm{K}$ ion was found to accumulate mostly in the leaves. In all other applications, it was determined that the accumulation of $\mathrm{K}$ ions in the root and stem decreased compared to the control group.

When the $\mathrm{Ca}$ ion in the root was examined, the highest value was found in $\mathrm{Ca} 5+$ Salt (3.642) application and the lowest value was found in $\mathrm{Ca} 1+$ Salt (0.798) application compared to control (4.245) group. Compared to the control group, the accumulation of calcium ions in the root was reduced in all other applications. When the amount of $\mathrm{Ca}$ in the stem was examined, the highest value was seen in $\mathrm{Ca} 1+$ Salt (2.343) application and the lowest value was found in $\mathrm{Ca}$ $2+$ Salt (0.813) application compared to control (1.693) group. When the amount of $\mathrm{Ca}$ in the leaves was 
examined, the highest value was found in $\mathrm{Ca} 4+$ Salt $(3,445)$ application and the lowest value was found in $\mathrm{Ca}$ $3+$ Salt $(1,867)$ application compared to control (2.105) group. Compared to the control group, it was observed that the calcium ion accumulation in the leaf increased in all applications except $\mathrm{Ca} 3+$ Salt application.

Table 4. Ca Ion accumulations determined in plant organs ( $\mu \mathrm{g} / \mathrm{mg}$ T.A.)

\begin{tabular}{|c|r|r|r|c|}
\hline Application & Root Ca & Stem Ca & Leaf Ca & P Value \\
\hline Control & $4.245 \mathrm{~A} \mathrm{a}$ & $1.693 \mathrm{BC} \mathrm{b}$ & $2.105 \mathrm{BC} \mathrm{b}$ & $0.0067^{*}$ \\
\hline $\mathrm{Ca} 1+\mathrm{NaCl}$ & $0.798 \mathrm{C} \mathrm{b}$ & $2.343 \mathrm{~A} \mathrm{a}$ & $2.807 \mathrm{AB} \mathrm{a}$ & $0.0006^{*}$ \\
\hline $\mathrm{Ca} 2+\mathrm{NaCl}$ & $2.934 \mathrm{~B} \mathrm{a}$ & $0.813 \mathrm{D} \mathrm{b}$ & $2.772 \mathrm{AB} \mathrm{a}$ & $0.0009^{*}$ \\
\hline $\mathrm{Ca} 3+\mathrm{NaCl}$ & $2.553 \mathrm{~B} \mathrm{a}$ & $1.319 \mathrm{C} \mathrm{b}$ & $1.867 \mathrm{C} \mathrm{ab}$ & $0.0580^{*}$ \\
\hline $\mathrm{Ca} 4+\mathrm{NaCl}$ & $3.561 \mathrm{AB} \mathrm{a}$ & $2.010 \mathrm{AB} \mathrm{b}$ & $3.445 \mathrm{~A} \mathrm{ab}$ & $0.0689^{*}$ \\
\hline $\mathrm{Ca} 5+\mathrm{NaCl}$ & $3.642 \mathrm{AB} \mathrm{a}$ & $1.665 \mathrm{BC} \mathrm{c}$ & $2.447 \mathrm{BC} \mathrm{b}$ & $0.0000^{*}$ \\
\hline $\mathrm{P} \mathrm{Value}$ & $0.0007^{*}$ & $0.0001^{*}$ & $0.0167^{*}$ & \\
\hline
\end{tabular}

Differences between means with the same superscript capital letter in the same column are not significant at $\mathrm{P} \leq 0.05$. Differences between means with the same superscript small letter in the same row are not significant at $\mathrm{P} \leq 0.05$.

Table 5. $\mathrm{Ca}^{+} / \mathrm{Na}^{+}$ratio determined in plant organs ( $\mu \mathrm{g} / \mathrm{mg}$ T.A.)

\begin{tabular}{|c|c|c|c|c|}
\hline Application & Root Ca/ Na & Stem Ca/Na & Leaf Ca/Na & P Value \\
\hline Control & $4.386 \mathrm{~A} \mathrm{a}$ & $1.384 \mathrm{~A} \mathrm{c}$ & $2.751 \mathrm{~A} \mathrm{~b}$ & $0.0002^{*}$ \\
\hline $\mathrm{Ca} 1+\mathrm{NaCl}$ & $0.279 \mathrm{D} \mathrm{b}$ & $0.337 \mathrm{~B} \mathrm{~b}$ & $0.651 \mathrm{~B} \mathrm{a}$ & $0.0016^{*}$ \\
\hline $\mathrm{Ca} 2+\mathrm{NaCl}$ & $1.063 \mathrm{BC} \mathrm{a}$ & $0.388 \mathrm{~B} \mathrm{c}$ & $0.744 \mathrm{~B} \mathrm{~b}$ & $0.0061^{*}$ \\
\hline $\mathrm{Ca} 3+\mathrm{NaCl}$ & $0.754 \mathrm{CD} \mathrm{a}$ & $0.397 \mathrm{~B} \mathrm{~b}$ & $0.708 \mathrm{~B} \mathrm{a}$ & $0.0310^{*}$ \\
\hline $\mathrm{Ca} 4+\mathrm{NaCl}$ & $1.257 \mathrm{BC} \mathrm{a}$ & $0.362 \mathrm{~B} \mathrm{c}$ & $0.821 \mathrm{~B} \mathrm{~b}$ & $0.0029^{*}$ \\
\hline $\mathrm{Ca} 5+\mathrm{NaCl}$ & $1.527 \mathrm{~B} \mathrm{a}$ & $0.452 \mathrm{~B} \mathrm{~b}$ & $0.837 \mathrm{~B} \mathrm{~b}$ & $0.0033^{*}$ \\
\hline $\mathrm{P}$ Value & $0.0000^{*}$ & $0.0000^{*}$ & $0.0000^{*}$ & \\
\hline
\end{tabular}

Differences between means with the same superscript capital letter in the same column are not significant at $\mathrm{P} \leq 0.05$. Differences between means with the same superscript small letter in the same row are not significant at $\mathrm{P} \leq 0.05$.

It was observed that $\mathrm{Ca}+/ \mathrm{Na}+$ ratio in root, stem and leaves decreased in all applications compared to control group. The highest $\mathrm{Ca}+/ \mathrm{Na}+$ ratio was observed in $\mathrm{Ca} 5$ + Salt application after control application.

Table 6. $\mathrm{Cl}$ ion accumulations determined in plant organs $(\mu \mathrm{g} /$ mg T.A.)

\begin{tabular}{|c|c|c|c|c|}
\hline Application & Root Cl & Stem Cl & Leaf Cl & P Value \\
\hline Control & $0.238 \mathrm{C} \mathrm{a}$ & $0.302 \mathrm{C} \mathrm{a}$ & $0.369 \mathrm{D} \mathrm{a}$ & $0.3486^{*}$ \\
\hline $\mathrm{Ca} 1+\mathrm{NaCl}$ & $1.41 \mathrm{AB} \mathrm{b}$ & $2.759 \mathrm{~A} \mathrm{a}$ & $2.584 \mathrm{~A} \mathrm{a}$ & $0.0025^{*}$ \\
\hline $\mathrm{Ca} 2+\mathrm{NaCl}$ & $1.311 \mathrm{AB} \mathrm{b}$ & $2.643 \mathrm{~A} \mathrm{a}$ & $1.745 \mathrm{~B} \mathrm{~b}$ & $0.0054^{*}$ \\
\hline $\mathrm{Ca} 3+\mathrm{NaCl}$ & $1.113 \mathrm{~B} \mathrm{~b}$ & $1.515 \mathrm{~B} \mathrm{a}$ & $1.244 \mathrm{C} \mathrm{b}$ & $0.0270^{*}$ \\
\hline $\mathrm{Ca} 4+\mathrm{NaCl}$ & $1.605 \mathrm{~A} \mathrm{~b}$ & $2.566 \mathrm{~A} \mathrm{a}$ & $2.220 \mathrm{~A} \mathrm{a}$ & $0.0121^{*}$ \\
\hline $\mathrm{Ca} 5+\mathrm{NaCl}$ & $1.602 \mathrm{~A} \mathrm{a}$ & $1.893 \mathrm{~B} \mathrm{a}$ & $1.523 \mathrm{BC} \mathrm{a}$ & $0.1232^{*}$ \\
\hline $\mathrm{P}$ Value & $0.0000^{*}$ & $0.0000^{*}$ & $0.0000^{*}$ & \\
\hline
\end{tabular}

Differences between means with the same superscript capital letter in the same column are not significant at $\mathrm{P} \leq 0.05$. Differences between means with the same superscript small letter in the same row are not significant at $\mathrm{P} \leq 0.05$.

When the $\mathrm{Cl}$ ions in the root were examined, the lowest value in terms of $\mathrm{Cl}$ ions was obtained from $\mathrm{Ca} 3$ + Salt $(1,113)$ application and the highest value was observed in Ca $4+$ Salt (1.605) application compared to the control (0.238) group. When the $\mathrm{Cl}$ ions in the stem were examined, the highest value was obtained from $\mathrm{Ca}$
$1+$ Salt (2.759) application and the lowest value was found in $\mathrm{Ca} 3+$ Salt (1.515) application compared to the control (0.302) group. When the $\mathrm{Cl}$ ion accumulation in the leaf was examined, the lowest value of this ion was observed in $\mathrm{Ca} 3$ + Salt (1.244) application and the highest value was observed in $\mathrm{Ca} 1+$ Salt (2.584) application compared to the control (0.369) group. In general, the amount of $\mathrm{Cl}$ ion was found to accumulate more in the stem part.

\section{Conclusion}

The results show that calcium uptake and transport in plants with high concentrations of salt is reduced. Thus leading to calcium deficiency and ion imbalance in the plant [4, 5]. Since calcium is an element having a positive effect on salt stress, high dose exogenous calcium decreases the permeability of the cell membrane against $\mathrm{Na}+$ ion, prevents the accumulation of sodium in the cell and in the plant by passive uptake and provides ion balance [7, 8], therefore, calcium protects plants against salt stress, and therefore plants are less affected by salt stress.

It is one of the most important reasons for the decrease and damage in the growth of pepper plants grown under the stress of salt, which is the amount of $\mathrm{Na}$ that they take from the environment by means of roots and accumulate in their bodies in excess and toxic level. Especially in low dose $\mathrm{Ca}$ applications, pepper plants accumulated higher $\mathrm{Na}$ in their stems. When the organs of the plants were examined in terms of $\mathrm{Na}$ accumulation, there was a balanced distribution of $\mathrm{Na}$ between all three organs and decreased intake. In the 4th application, it is seen that the ion uptake is reduced and there is a balanced distribution. Ion regulation is one of the most important features seen in plants with high tolerance to salt.

The results obtained in our study showed that the appropriate $\mathrm{Ca}$ dose (4th application) adjusted the ion uptake and distribution well. Plants with high $\mathrm{NaCl}$ salt concentration receive excessive $\mathrm{Na}$ ions. The uptake of $\mathrm{Ca}$ and $\mathrm{K}$ ions, which is very similar to sodium ion due to their ionic diameters and electrical charges, is prevented.

On the other hand, if the appropriate $\mathrm{Ca}$ application is performed, the uptake of low $\mathrm{Na}$ and $\mathrm{Cl}$ ions under salt conditions as well as higher $\mathrm{K}$ and $\mathrm{Ca}$ uptake increases are the key mechanisms of tolerance. Tissues of plants with better tolerance to salt stress are generally capable of producing a higher $\mathrm{Ca} / \mathrm{Na}$ and $\mathrm{K} / \mathrm{Na}$ ratio. This means that plants can be protected from the negative effects of salt stress if $\mathrm{Ca}$ is applied at the appropriate rate. Many studies to determine tolerance to salt stress in plants (eggplant, beans, melons, tomatoes and peppers), $\mathrm{K} / \mathrm{Na}, \mathrm{Ca} / \mathrm{Na}$ ratios in different plant organs and the determination of $\mathrm{Na}$ concentrations in plant tissues is an important parameter [14-17].

One of the most striking results in our study; As the $\mathrm{Ca}$ ion dose increases, there is an increase in the amount of $\mathrm{K}$ ions in the roots, stems and leaves of pepper plants. At the same time, it was observed that there was an 
increase as it went up from the roots to the leaves. Especially in the 3rd dose of $\mathrm{Ca}$, there was a significant increase in $\mathrm{K}$ accumulation in the leaves compared to the control.

In plants grown in soil conditions where salt is high, a high proportion of $\mathrm{Na}$ ions are taken by the roots and the amount of this ion is increased by transporting this ion to the plant organs. Due to the decrease in $\mathrm{K}$ and $\mathrm{Ca}$ uptake and transport, their proportion in plant organs decreases. While $\mathrm{Ca}$ and $\mathrm{K}$ ions play a key role in physiological events, $\mathrm{Na}$ has no effect as a nutrient. In addition, the increase of $\mathrm{Na}$ ion against $\mathrm{K}$ and $\mathrm{Ca}$ ions causes ion imbalance [18].

The application of $\mathrm{Ca}$ in different doses of nutrient solution given to pepper plants grown in salt stress environment revealed differences in $\mathrm{Ca}$ intake of plants naturally. The main objective, however, is to determine which dose of Ca reduces the salt stress effect and which dose will achieve ion balance in Ca uptake. In our study, different results were obtained at different doses. There was no systematic increase in doses in all three organs. In particular, a reduction in intake of $\mathrm{Ca} 4$ was observed. Calcium is less accumulated in the stem, while it is higher in the roots and leaves. $\mathrm{Ca} / \mathrm{Na}$ ratio is very important in the process uptake of calcium from the roots.

The presence of high amounts of sodium in the nutrient medium reduces calcium uptake. In such saline conditions, when extra $\mathrm{Ca}$ is given to plants, it may be mentioned that sodium in the plasma of the root hairs can be replaced by calcium, and it is stated that there may be decreases in $\mathrm{Na}$ uptake and therefore stressreducing effect [19]. Yaşar et al. [20] under salt stress, two sensitive and two tolerant eggplant varieties used in the study, $\mathrm{Na}$ and $\mathrm{Cl}$ ion accumulation was found to be higher in the genotype sensitive. They reported a decrease in the $\mathrm{K}$ and $\mathrm{Ca}$ amounts of these genotypes. Tolerant genotypes showed a decrease in $\mathrm{Na}$ and $\mathrm{Cl}$ uptake and an increase in $\mathrm{K}$ and $\mathrm{Ca}$ uptake. Yaşar et al., [21, 22], Üzal, [23], Üzal and Y1ldı, [24] showed that $\mathrm{K}$ and $\mathrm{Ca}$ uptake had a significant effect on salt stress tolerance in plants.

It was observed that there are differences in $\mathrm{Cl}$ accumulation in root, stem and leaves of pepper plants according to calcium doses. $\mathrm{Cl}$ increased in all organs compared to control. For $\mathrm{Cl}$, we cannot see a systematic decrease or increase due to the increase in $\mathrm{Ca}$ doses. However, a more important result is that the 4th dose of $\mathrm{Ca}$ also proved to be the most appropriate dose in $\mathrm{Cl}$ uptake. The 4th dose had a significant positive effect on both $\mathrm{Cl}$ intake and distribution. The closest control value in terms of $\mathrm{Cl}$ uptake was obtained from plants grown at the 4th dose of $\mathrm{Ca}$. It has been reported that $\mathrm{Cl}$ accumulation increases in plants under salt stress, but in studies conducted in different species, the increase in tolerant ones is less [14-16, 23].

The results obtained from these studies and our studies showed that the 4 th dose of $\mathrm{Ca}$ decreased $\mathrm{Cl}$ intake and thus provided a tolerance to salt stress in plants. As a result, proper doses of $\mathrm{Ca}$ can protect the plant from the toxic effect of salt by maintaining ion balance in the cell, even under salt stress.

\section{References}

1. A.K. Parida, A.B. Das, Salt Tolerance and Salinity Effects on Plants, a Review, Ecotoxicol. and Environm. Safety, 60, 324-349 (2005)

2. X. Niu, R.A. Bressan, P.M. Hasegawa, J.M. Pardo, Ion Homeostasis in Nacl Stress Environments, Plant Physiol., 109(3), 735 (1995)

3. N. Tuteja, Mechanisms of High Salinity Tolerance in Plants, Meth. in Enzymol., 428, 419-438 (Academic Press, 2007)

4. G.R. Cramer, A. Läuchli, E. Epstein, Effects of Nacl and Cacl 2 on Ion Activities in Complex Nutrient Solutions and Root Growth of Cotton, Plant Physiol., 81(3), 792-797 (1986)

5. J. Huang, R.E. Redmann, Solute Adjustment to Salinity and Calcium Supply in Cultivated and Wild Barley, J. of Plant Nutrit., 18(7), 1371-1389 (1995)

6. P.M. Hasegawa, R.A. Bressan, J.K. Zhu, H.J. Bohnert, Plant Cellular and Molecular Responses to High Salinity, Annual Review of Plant Biol., 51(1), 463-499 (2000)

7. R. Hoffmann, J. Tufariello, M.A. Bisson, Effect of Divalent Cations on $\mathrm{Na}+$ Permeability of Chara Corallina and Freshwater Grown Chara Buckellii, J. of Experim. Botany, 40(8), 875-881 (1989)

8. J. Whittington, F.A. Smith, Calcium-Salinity Interactions Affect Ion Transport in Chara Corallina, Plant, Cell \& Environment, 15(6), 727733 (1992)

9. A. Lauchil, Calcium, Salinity and the Plasma Membrane, Calc. in Plant Growth and Developm., 26-35 (1990)

10. Z. Rengel, The role of calcium in salt toxicity, Plant, Cell and Environm., 15, 625-632 (1992)

11. D.R. Hoagland, D.I. Arnon, The Water Culture Method for Growing Plants Without Soil, Circular California Agricult. Experim. Station., 1, 347-461 (1938)

12. B. Kacar, Bitki ve Topră̆ın Kimyasal Analizleri. III Toprak Analizleri (Ankara Üniversitesi Ziraat Fakültesi Eğitim, Araştırma ve Geliştirme Vakfı Yayınları: 3, Ankara, 1994)

13. E. Taleisnik, G. Peyran, C. Arias, Respose of Chlorisgayana Cultivars to Salinity. 1. Germination and Early Vegetatif Growth, Tropical Grassland, 31, 232-240 (1997)

14. F. Yaşar, Invitro And In Vivo Investigation Of Some Antioxidant Enzyme Activities In Atiplant Genotics Under Salt Stress, PhD Thesis Not Published (Van Yuzuncu Yil University, Institute of Science and Technology, Van, 2003)

15. H. Aktas, K. Abak, I. Cakmak, Genotypic Variation in The Response of Pepper to Salinity, Sciantia Hort, 110, 260-266 (2006)

16. Ş. Kuşvuran, Ş. Ellialtıoğlu, K. Abak, F. Yaşar, Responses of Some Melon (Cucumis Sp.) Genotypes to Salt Stress, J. of Agricult. Sci. (Turkey, 2007) 
17. H.Y. Dasgan, S. Koc, Evaluation of Salt Tolerance in Common Bean Genotypes by Ion Regulation and Searching for Screening Parameters, J. of Food, Agricult. Environm., 7(2), 363-372 (2009)

18. G.N. Al-Karaki, Growth, Water Use Efficiency, and Sodium and Potassium Acquisition by Tomato Cultivars Grown Under Salt Stress, J. of Plant Nutrit., 23(1), 1-8 (2000)

19. C. Kemmler, A. Krauss, $K$ and stress tolerance Büntheof Agriculture, Research station of Kali und Salz A.C. Bünteweg 8, D-3000 (Hannover, 1971)

20. F. Yaşar, S. Ellialtıoglu, S. Kusvuran, Ion and Lipid Peroxide Content in Sensitive and Tolerant Eggplant Callus Cultured Under Salt Stress, Europ. J. of Hortıcult. Sc1., 71(4), 169-172 (2006a)

21. F. Yasar, O. Uzal, S. Tufenkci, K. Yildiz, Ion Accumulation in Different Organs of Green Bean Genotypes Grown Under Salt Stres, Europ. J. of Hortıcult. Sc1., 71, 169-172 (2006b)
22. F. Yasar, O. Uzal, O. Yasar, Identification of Ion Accumulation and Distribution Mechanisms in Watermelon Seedlings (Citrullus lanatus (Thunb.) Mansf.) Grown under Salt Stress, Yüzüncü Y1l Üniversitesi Tarım Bilimleri Dergisi, 23(3), 209214 (2013)

23. Ö. Üzal, Effects of Jasmonic Acid on Plant Growth and Antioxidant Enzyme Activities in Some Strawberry Cultivars Grown Under Salt Stress, $\mathrm{PhD}$ dissertation thesis (Graduate School of Natural and Applied Sciences, Department of Horticulture, Van, 2009)

24. Ö. Üzal, K. Yıldız, Bazı Çilek (Fragaria $X$ Ananassa L.) Çeşitlerinin Tuz Stresine Tepkileri. Reactions to Salt Stress of Some Strawberry (Fragaria X Ananassa L.), Cultivars Yüzüncü Y1l Univer. J. of Agricult. Sci., 24(2), 159167 (2014) 